This item was submitted to Loughborough's Research Repository by the author.

Items in Figshare are protected by copyright, with all rights reserved, unless otherwise indicated.

\title{
Sport identification and employee pride: key factors in sport employee psychology
}

PLEASE CITE THE PUBLISHED VERSION

http://dx.doi.org/10.1504/IJSMM.2017.10004823

\section{PUBLISHER}

(C) Inderscience Enterprises Ltd.

\section{VERSION}

AM (Accepted Manuscript)

\section{PUBLISHER STATEMENT}

This work is made available according to the conditions of the Creative Commons Attribution-NonCommercialNoDerivatives 4.0 International (CC BY-NC-ND 4.0) licence. Full details of this licence are available at: https://creativecommons.org/licenses/by-nc-nd/4.0/

\section{LICENCE}

CC BY-NC-ND 4.0

\section{REPOSITORY RECORD}

Swanson, Steve, and Aubrey Kent. 2019. "Sport Identification and Employee Pride: Key Factors in Sport Employee Psychology”. figshare. https://hdl.handle.net/2134/23494. 


\title{
Sport Identification and Employee Pride:
}

\section{Key Factors in Sport Employee Psychology}

\begin{abstract}
The current study used a positive psychology approach to gain insight on employees working within the professional sports industry. While psychological fulfillment has been proposed as a critical area of distinction for managing in the sport environment, there is a need for empirical investigation relating to this proposition. The purpose of the current study was to address this gap in the literature and assess the role of psychological fulfillment in the form of sport employee pride. This study also addresses the role of identification with a specific sport and introduces this concept to the organisational behaviour literature more generally. More than 1,000 employees from five different professional sports leagues participated in the study, with structural equation modelling results providing support for sport identification and employee pride having a positive influence on satisfaction and organisational citizenship behaviour. Implications for sport managers are that employees working in this environment can have a psychological connection with a particular sport, which in turn augments employee pride and leads to positive attitudes and behaviours in the workplace. The results of this study are significant to sport managers in relation to human resource decisions and promoting positive psychology in the workplace.
\end{abstract}




\section{Introduction}

Despite calls for investigation of organisational life and human resource management in the sport environment (Doherty, 1998; Todd and Kent, 2009), the sport management discipline has generally given more attention to other areas of the field such as sport marketing and consumer behaviour (e.g., Dickson, Naylor and Phelps, 2015), sport sponsorship (e.g., Abeza, Pegoraro, Naraine, Séguin and O'Reilly, 2014), and more recently sport for development (e.g., MacIntosh, Arellano and Forneris, 2016). In addressing this need for additional human resource management research, the current study views sport organisations through the lens of 'positive psychology' espoused by Seligman and Csikszentmihalyi (2000). The aim of this perspective is to promote a focus on the positive qualities of individuals rather than being preoccupied with attempts to repair those which are less desirable (Seligman and Csikszentmihalyi, 2000). This line of thinking has also had a large impact on the organisational behaviour discipline, with some scholars proposing the development and management of 'positive organisational behaviour' (POB) should be a primary focus of organisational research (e.g., Luthans, 2002; Wright, 2003).

Todd and Kent (2009) used a similar approach by conceptualising 'positive social identity' (PSI) as a key construct which sport employees may experience in excess of what is seen in other industries. In absence of the development of a specific measure of PSI as called for by those authors, the current study offers employee pride as a close conceptual proxy which can currently be operationalised for empirical investigation of their conceptual model. Utilising employee pride as a closely related concept provides an avenue to investigate Todd and Kent's (2009) propositions more effectively from the POB perspective, as a main principle of this approach is to study psychological capacities which can be effectively measured (Luthans, 2000). Consistent with the positive psychology perspective, the current study also investigates 
the impact of employee pride on organisational citizenship and the general satisfaction with one’s job (e.g., Seligman and Csikszentmihalyi, 2000; Todd and Kent, 2009).

In addition to addressing Todd and Kent's (2009) recommendation for empirically testing their model of psychological fulfillment in the sport workplace, the current investigation also addresses the call to examine sport-specific targets of identification in this setting (Swanson and Kent, 2015). Building on the multi-target approach to identification in organisations (Ashforth, Harrison and Corley, 2008; Ashforth and Johnson, 2001), Swanson and Kent (2015) found that sport employees are indeed discretely capable of identifying with a specific sports team whilst working within the professional sports industry. In the current study we look to extend these findings and also address their specific call to examine the role of sport identification for employees working within the context of sport.

As Todd and Kent (2009) have proposed psychological fulfillment as a critical area of distinction for managing in the sport environment, there is a need for empirical investigation relating to their theoretical propositions. The purpose of the current study is to address this gap in the literature and assess the role of psychological fulfillment in the form of sport employee pride. In addition, we also address the role of identification with a specific sport in this setting, and introduce this concept to the organisational behaviour literature more generally. This approach also addresses the call for research grounded solely in the sport context as a means for theory building, and proving distinct managerial considerations for the sport management discipline (Chalip 2006; Slack, 1996). The current study therefore investigates sport-relevant attitudes to which managers may need to pay particular attention when pursuing positive organisational behaviour in the sport workplace. 


\section{Theoretical Background}

\section{Psychological Fulfillment in the Sport Workplace}

In their conceptual paper on employee attitudes in sport, Todd and Kent (2009) focused on the psychological fulfillment experienced whilst working in the sport industry, and developed a theoretical model outlining the antecedents and consequences of this phenomenon. Drawing from social identity theory (e.g., Tajfel and Turner, 1986), they argued that this psychological fulfillment consists of emotionally significant benefits (e.g., pride and self-esteem) which employees receive when working for organisations perceived as having high social status. For example Todd and Kent (2009) proposed that various aspects of an employee's job situation can contribute to this fulfillment, such as the construed external image and member attraction associated with their organisation. Construed external image refers to employees' perceptions of how outsiders view their organisation in relation to elements such as reputation, prestige, and popularity (Dutton, Dukerich, and Harquail, 1994; Todd and Kent, 2009). Member attraction relates to an employee's desire to identify with and be accepted in an organisation, and stems from the perception of person-organisation fit and the perceived benefits of being a member (Evans and Jarvis, 1986; Todd and Kent, 2009). Taken together, these areas provide two broad pathways through which employees may derive enhanced psychological fulfillment while working in the sport environment (Todd and Kent, 2009).

In an effort to appropriately label their notion of psychological fulfillment for sport employees, Todd and Kent (2009) borrowed from the social psychology literature and referred to this phenomenon as positive social identity, calling for future research to create an appropriate measure of this concept. In the current paper we consider the potential for this type of psychological fulfillment to include other constructs which each serve as indicators for the 
positive psychology of employees working in sport. Tyler and Blader (2001), for example, consider the concepts of respect and pride to effectively be measures of an individual's social identity as they reflect judgements about social status within and between groups, and are both ultimately an indication of how good people feel about themselves.

With regard to pride in the workplace, Todd and Kent (2009) argue this concept is indeed one area of psychological fulfillment which can be experienced through 'member benefits' afforded to employees working in high status sporting environments. For example, individuals working for professional sport organisations often receive benefits such as tickets to highly promoted sport contests, exclusive apparel, access to restricted areas with in stadia, and personal contact with high profile athletes. In turn, enhanced psychological fulfillment can therefore be experienced via employee recognition of these unique opportunities, and continually enhanced through discussion of these experiences with outsiders to the organisation.

As this conceptualisation of psychological fulfillment may indeed be difficult to appropriately capture (Todd and Kent, 2009), and on the basis that pride can serve as an appropriate measure of one's positive social identity (Tyler and Blader, 2001), we propose pride in the workplace as a concept closely linked to Todd and Kent's (2009) central concept and model of employee attitudes in this context. The following section outlines how the current paper embeds sport employee pride at the centre of this process and elaborates on a context-specific antecedent and key outcomes which may be specifically linked to this concept.

--- INSERT FIGURE 1 ABOUT HERE ---

\section{Overview of the Conceptual Model}

The current study looks to employ the concept of employee pride as a central component of Todd and Kent's (2009) model of the employee attitudes in sport. Figure 1 outlines the 
conceptual model for the current study, with pride representing the psychological fulfillment experienced by employees working in the professional sporting environment. In line with Todd and Kent's (2009) theoretical mapping, the current model proposes that employee pride will lead to an increased level of job satisfaction and organisational citizenship behaviour. The current model also draws on the identification literature by considering a focus of identification which is highly relevant to the professional sport environment. Specifically, the conceptual model indicates that identification with the specific sport one's organisation is affiliated with will increase the level of pride that employees experience in association with their organisational roles. Following recent findings indicating that sport employees can identify with other sportspecific foci (Swanson and Kent, 2015), the current model extends this line of research and considers additional targets of identification which may be present in this specific organisational environment (e.g., Ashforth et al., 2008; Ashforth and Johnson, 2001).

\section{Foci of Identification in Professional Sport}

A great deal of research has addressed the role of organisational identification in various different literature streams, which is in large part due to the broad spectrum of outcomes associated with this construct (Ashforth et al., 2008). Stemming from Ashforth and Johnson's (2001) work on identification with various categories, the organisational identification literature has long recognised that employees can identify with multiple targets (or foci) of identification within their given context. For example, beyond identifying with the organisation as a whole, increased attention has also been given to employee identification with relevant organisational entities such as departments, workgroups, committees, and social groups (e.g., Ashforth and Johnson, 2001). 
Building from this perspective, Swanson and Kent (2015) developed a framework for professional sport organisations which also accounted for employee identification with the affiliated sports teams. This research indicated that employees working in the professional sport environment could indeed identify, in a distinct and separate way, with both their overall employing organisation and the actual team in the arena. Recognising that employees in this context are often fans of their organisation's actual sport team (e.g., players and coaches), the authors noted that earlier depictions of organisational identification did not account for such circumstances. More specifically, the mainstream approach to organisational identification categories had previously only included entities where the employees were formal members of the group (e.g., department or work team). With large amounts of attention given to professional sport teams by their organisational staff, Swanson and Kent (2015) proposed that employees in this setting can transcend the traditional organisational categories and also have a significant psychological connection (e.g., Wann, 1997; Wann and Branscombe, 1990) with other relevant facets of their specific context. The current research looks to extend Swanson and Kent's (2015) model and consider how identifying with a specific sport might also play a role in this environment.

\section{Pride in the Sport Workplace}

Aristotle (384-322 BCE) first referred to pride as a fundamental moral virtue (Sokolowski, 2001) relating to dignity and experiences of feeling valuable as a person (Wärnå, Lindholm and Eriksson, 2007). The notion of pride is also closely connected to the sporting environment in a variety of ways. Feelings of pride are associated with hard work and success (e.g., Maraniss, 1999) and are generally considered to be worthy of pursuit for a wide variety of participants (e.g., players, coaches, etc.). For instance, a common view in the area of sport 
psychology is that coaches should work to instill pride in their players in the interest of fostering team cohesion and on-field success (e.g., Weinberg and Gould, 2011). In the sport management literature, sport has also been identified as an important factor in a variety of situations. For example, national pride has been viewed as playing a critical role in developing national identity (Chalip, 2006), and also seen as a significant benefit of hosting sporting events (e.g., Heere et al., 2013; Misener and Mason, 2009). In addition, pride has also been viewed as an important benefit of volunteering at international sporting events (Bang and Chelladurai, 2009) and more generally as one of the tangible effects of the sport fan experience (Wann, 2006). Pride has also been considered a foundational element of fan behaviour, leading to significant outcomes such as loyalty, commitment and increased consumption (Decrop and Derbaix, 2010).

The notion of pride has been conceptualised in the management and organisational behaviour literatures with both emotional and evaluative perspectives. While some viewpoints appear to view pride as more of an evaluation of status and general worth (e.g., Blader and Tyler, 2009), others have placed more of an emphasis on the emotional aspects of the construct (e.g., Horberg, Kraus and Keltner, 2013). Using a balanced approach accounting for these perspectives, our conceptualisation of pride is consistent with Smith and Tyler's (1997, p. 165) view of pride as a "measure of affective and evaluative feelings" about an attitudinal object. From this viewpoint, we consider sport employee pride to represent feelings of importance, value, and admiration based on status evaluations of one's current job (Todd and Harris, 2009; Tyler and Blader, 2001). Previous research has indicated that pride is positively associated with a several important organisational constructs, such as organisational commitment (Ellemers, Kingma, van de Burgt and Barreto, 2011), self-efficacy (Todd and Harris, 2009), compliance, satisfaction, and intentions to stay (Tyler and Blader, 2001). Employee pride has indeed been 
considered a strategic asset which is closely associated with performance and organisational success (Katzenbach, 2003a; 2003b). However with many such views based in large part on intuition and anecdotes (Gouthier and Rhien, 2011), more empirical investigation on the role of employee pride is needed to gain insight in this area.

\section{Theoretical Development}

Identification with specific sports. Elements of organisational behaviour which have specific relevance to the sport context have recently garnered attention in the sport management literature (e.g., Swanson and Kent, 2014; Swanson and Kent, 2015). For example, team identification has also recently been identified as a significant predictor of outcomes which are relevant to individuals working inside sport organisations (Swanson and Kent, 2015). The concept of team identification has been widely researched in the area of consumer behaviour, and refers to the psychological connection that individuals have with a specific sports team (Wann, 1997; Wann and Branscombe, 1990). In a similar fashion to team identification, we propose that individuals can also identify with the affiliated sport of their employing organisation. Employees are often drawn to work in the sport industry due in part to their affinity for sport (Taylor et al., 2008), and individuals are also generally able to identify which sports are their favourite (e.g., Caspar and Menefee, 2010). As educators in sport management, we anecdotally recognise that a common theme with our students is to be largely interested in working for organisations affiliated with a specific sport (e.g., premier league football), rather than considering more fully the functional areas or departments (e.g., marketing, sales, etc.) where their individual skill sets would be most appropriately suited. Support for this phenomenon has also been demonstrated empirically, with previous research indicating that the 
love of sport plays a larger role than knowledge about specific jobs when assessing the appropriateness of working for an organisation in the sport industry (Todd and Andrew, 2008).

Beyond being aware of their favourite sports, previous research indicates that individuals are also able to identify with the specific type of sport (Dittmore, Stoldt and Greenwell, 2008; Trail, Robinson, Dick and Valentine, 2003). For example, Trail et al. (2003) noted that most literature has limited its scope to solely focusing on identification with a team, rather than accounting for other likely points of attachment like their favourite sports. Addressing this issue, the authors developed a model which differentiated between organisational identification and identification with the specific type of sport. More specifically, Trail et al. (2003) specified sport identification as a latent construct accounting for both the type of sport (football, basketball, etc.) and the level of sport (e.g., professional, university, etc.), with structural equation modeling results providing support for a sport being a target of identification which stemmed from various fan motivations. For example, appreciation of a sport's aesthetic beauty, the required physical skill set, and the drama associated game outcomes are all aspects of specific sports which people are drawn to in different ways (Trail et al., 2003). In a like manner with team identification, we therefore propose that individuals working in sport can also have a psychological connection with the specific sport affiliated with their employing organisation (Dittmore et al., 2008; Trail et al., 2003).

Sport identification as a contributor to employee pride. As pride in the organisational setting is comprised of feelings of value, importance, and admiration based on status evaluations made by employees (Todd and Harris, 2009; Tyler and Blader, 2001), its antecedents generally consist of constructs which can facilitate these cognitive and emotional elements. For example, Tyler and Blader (2001) indicate that prestigious aspects of one's job situation can make 
individuals feel good about themselves and positively impact employee pride levels. We argue that employees working in professional sport will generally consider sport to be prestigious in nature, and identifying with such a category will lead to similar results.

As individuals associated with sport often consider themselves to be specifically aligned with a certain sport, and refer to themselves as a "football person" (e.g., Rowe, Markwell and Stevenson, 2006, p. 157) or a 'hockey guy' (e.g., Gau and Woodside, 2014, p. 40), it appears that individuals do indeed define themselves in relation to specific types of sport (e.g., Ashforth and Mael, 1989). From a social identity perspective, the specific sport environment that individuals work in can constitute one part of self-definition that comes from being a part of a specific category of membership (Tajfel, 1978). As the social identity approach maintains that a positive social identity stems from favourable in-group versus out-group comparisons (Tajfel and Tuner, 1979), we propose that professional sport employees are able to experience the positive psychological fulfillment and be proud of the specific sport industry they are employed in. Beyond the prestige generally associated with sport (Todd and Kent, 209) and the sport's specific attributes as outlined above, various other favourable characteristics are also readily available for sport employees to take pride in. For example, other references such as "national pastime" (MLB.com, 2016) for American-based baseball, rugby as the "toughest sport in the world" (Shermilt, 2013), and football (soccer) as the "most popular sport in the world" (BBC.co.uk, 2016) provide descriptions through which individuals might also experience a sense of pride.

Employees in professional sport can also experience psychological fulfillment through an increased sense of congruence with their organisational environment (Swanson and Kent, 2015; Todd and Kent, 2009). Referencing the disproportionate number of applications for jobs in 
professional sport organisations, Todd and Kent (2009) proposed that member attraction (e.g., Schneider, 1987) was also a contributor to experience enhanced psychological fulfillment in the sport workplace. We argue that a psychological connection with a sport which is highly relevant to the context will be perceived as an attractive congruence of values (e.g., Cable and Judge, 1996) which then leads to increased levels of employee pride. As employees who are also sports fans can experience a sense of alignment with the goals of their workplace environment (Swanson and Kent, 2015), sport identification may also lead to prideful feelings through the recognition of being in a highly sought after job situation (Todd and Harris, 2009).

Finally, with the strong relationship between sport and emotion (Vallerand and Blanchard, 2000), there is also potential for sport identification to lead to increased levels of pride through emotional channels. As being a sports fan is frequently associated with emotional responses, and environmental aspects of sport (e.g., stadia) can often trigger a sense of pride (Wann, 2006), the day-to-day exposure to a specific sport an individual has a strong connection with may indeed nurture the feeling of pride experienced by employees working in this setting. In sum, we therefore propose that sport identification will enhance employee pride by providing positive feelings of value, importance, and admiration (Todd and Harris, 2009; Tyler and Blader, 2001).

Hypothesis 1: Sport identification will be positively related to employee pride for employees in professional sport organisations.

Job satisfaction as an outcome of pride. As pride is conceptualised as the feeling of importance and admiration based on an individual's job status, it is expected that employee pride will have a positive influence on the organisationally desirable outcomes included in the conceptual model. While pride in the workplace has not received a large amount of attention in the literature (Gouthier and Rhein, 2011), previous investigations have indicated a positive 
relationship with key workplace outcomes such as job self-efficacy (Todd and Harris, 2009) and intentions to stay in their organisation (Tyler and Blader, 2001). We first propose that employee pride will have a positive effect on job satisfaction in the professional sport setting. Job satisfaction is an overall assessment of the extent to which employees are generally happy with their job (Hackman and Oldham, 1975). As employees experience positive feelings and evaluations relating to their job's importance and value (Todd and Harris, 2009; Tyler and Blader, 2001), it follows that this should then lead to a positive assessment of their current job experience (Hackman and Oldham, 1975). There is also some empirical support in the literature for this argument, as pride has also been shown to have a positive influence on satisfaction with work (Ellemers et al., 2011) and with one's job and supervisor (Tyler and Blader, 2001). As the psychological fulfillment experienced by those working in the current research setting is thought to be relatively high (Todd and Kent, 2009), we propose that employee pride is in line with this notion and will lead to a general satisfaction with one's job.

Hypothesis 2: Employee pride will be positively related to job satisfaction for employees in professional sport organisations.

Organisational citizenship behaviour as an outcome of pride. Organisational citizenship behaviour refer to those which are of a discretionary nature and are not explicitly acknowledged within a formal reward system, yet still promote the effective functioning of an organisation (Ferrin, Dirks and Shah, 2006; Organ, 1988). We propose that employee pride will also lead to prosocial behaviours which are beyond contractual responsibilities, as pride is a direct measure of status which is closely linked to cooperative behaviour (Todd and Kent, 2009; Tyler, 2001). The literature generally indicates that members of groups demonstrate cooperative behaviour to the extent they perceive their membership to be high in status (Tyler and Blader, 
2001). The general thesis for this prediction is that individuals who evaluate their group in a positive fashion will internalise group interests and effectively equate them with their own (Brewer and Kramer, 1986; Tyler, Degoey and Smith, 1996). As pride incorporates feelings of importance, value, and admiration based on job status (Todd and Harris, 2009; Tyler and Blader, 2001), employees working in the high profile sports environment would be expected to internalise the interests of the organisation as their own and engage in cooperative behaviour that is beneficial to the organisation (Tyler, 2001; Tyler et al., 1996). Some relevant examples of organisational citizenship behaviour include attending voluntary events that help the organisation's image and defending the organisation in the face of criticism (Lee and Allen, 2002). As the sport environment is ripe with opportunities to engage in these types of extra-role opportunities (e.g., volunteering for community functions and defending the organisation during losing streaks), it follows that higher levels of employee pride should also have a positive effect on organisational citizenship behaviour.

Hypothesis 3: Employee pride will be positively related to organisational citizenship behaviour for employees in professional sport organisations.

\section{Methods}

\section{Sample and Measures}

The participants for the study were employees from 98 randomly sampled organisations from Major League Baseball (MLB), Major League Soccer (MLS), the National Basketball Association (NBA), the National Football League (NFL), and the National Hockey League (NHL). These people were business operations employees working in departmental areas such as marketing, sales, accounting, and communications. Proportional stratified sampling (e.g., Leedy and Ormrod, 2001) was utilised to provide the same proportion of representation across the various leagues. This process consisted of randomly selecting $70 \%$ of the organisations in each 
league for sampling, with online surveys then sent to a total of 9,333 employees across all leagues. A final sample of 1,082 participants completed the survey (11.6\% response), and the participants were $66.0 \%$ male, $84.4 \%$ Caucasian, had an average age of 35.8 years, and has been with their current organisation for an average of 5.5 years. With regard to league representation, $33.5 \%$ of the sample was from MLB, $6.1 \%$ from MLS, $19.8 \%$ from the NBA, $18.1 \%$ from the NFL, and $22.5 \%$ from the NHL.

The following survey items were used with a five-point Likert-type scale unless otherwise specified $(1=$ strongly disagree and $5=$ strongly agree $)$. Job pride was measured using the three-item scale developed by Todd and Harris (2009), with and an example item being "In social settings, I feel valued and admired because of my job." Sport identification was measured using four items from the Sport Spectator Identification Scale (Wann and Branscombe, 1993). These items were modified to focus the respondent on the specific sport (e.g., football, basketball, etc.) of the employee's respective league. Following Swanson and Kent (2015), one of the items was also modified from the original scale to make more appropriate for employees working in sport. A sample item from this scale is "How important is being a fan of basketball in general to you," and these items were captured with an eight-point Likert-type scale (e.g., $1=$ not important and $8=$ very important). Job satisfaction was assessed with Cammann, Fichman, Jennkins, and Klesh's (1983) three-item scale, with a sample item being “Overall, I am satisfied with my job.” Finally, organisational citizenship behaviour was measured using three-items from Lee and Allen's (2002) scale for citizenship behaviour directed toward the organisation. A sample item from this scale is "I attend functions that are not required but that help the organization's image," and these items were captured with a seven-point Likert-type scale $(1=$ strongly disagree and 7 = strongly agree) . 


\section{Data Analysis and Results}

Measurement model analysis. Structural equation modeling was utilised to assess the hypothesised relationships using a two-step modeling process (Anderson and Gerbing, 1988). The measurement model specified the preceding survey items loading onto their respective constructs, and all analysis utilised maximum likelihood estimation with robust standard errors (MLR) (Muthén and Muthén, 1998-2012). All of the individual factor loadings were significant and above the .5 level (Hair, Black, Babin, Anderson and Tatham, 2006; Hulland, 1999) and the measurement model indicated good fit with the data $\left(\chi^{2}=186, d f=59, \mathrm{CFI}=.98, \mathrm{TLI}=.97\right.$, RMSEA $=.05$, SRMR $=.03)$. The convergent validity of the five constructs was analysed by assessing both the construct reliability (CR) and average variance extracted (AVE) for each of the latent constructs (Fornell and Larcker, 1981). The CR and AVE levels were all above .7 and .5 , respectively, with only one exception (AVE=.44 for organisational citizenship behaviour). This one exception was deemed acceptable for the current analysis as AVE is a conservative measure which is often below the .5 level (Jiang, Klein and Carr, 2002). Support for the discriminant validity was also demonstrated with all construct AVE values being greater than the squared interconstruct correlations (Fornell and Larcker, 1981). The correlation matrix is provided in Table 1 along with the aggregate means, Chronbach's alpha, CR, and AVE values for all of the constructs. The measurement model was then utilised to assess the structural model as discussed in the next section.

--- INSERT TABLE 1 ABOUT HERE ---

Structural model analysis. Consistent with the hypothesised relationships, the structural model was specified with sport identification leading to employee pride, which in turn led to job satisfaction and organisational citizenship behaviour. To account for the potential of increased 
sport fandom and employee pride experienced when the respective leagues were in season, a dummy variable (in-season 1; off-season 0 ) was included in the model. As the length of time with an organisation can affect attitudes in the workplace (Cardador, Dane and Pratt, 2011) organisational tenure was also controlled for in the analysis. In a similar fashion with measurement model, the results of the hypothesised structural model also indicated acceptable fit with the data $(\chi 2=287, d f=81, \mathrm{CFI}=.97, \mathrm{TLI}=.96, \mathrm{RMSEA}=.05, \mathrm{SRMR}=.07)$, and support was found for all of the hypothesised relationships. After acceptable fit was determined for the hypothesised model (Model 1), two alternative models were also assessed in connection with the literature. First, as previous work has indicated that identification with sport-specific foci (e.g., team identification) may lead to increased levels of employee satisfaction (Swanson and Kent, 2015), Model 2 specified an additional path from sport identification to job satisfaction to assess the potential link between these constructs. Results from a chi-square difference test indicated significantly better fit with the data $\left(\Delta \chi_{(I)}=9, \mathrm{p}<.01\right)$ so Model 2 was retained as the more representative model. Next, with organisational citizenship behaviour being related to concepts such as teamwork, sportsmanship, and cheerleading (Organ, 1988;1990), we assessed the potential for sport identification to also have a direct link with the organisational citizenship behaviour. On the basis that an increased sense of psychological connection with a team sport may be related to behaviour of this kind, Model 3 specified an additional path from sport identification to organisational citizenship behaviour. With results from the chi-square square difference test indicating that Model 3 had significantly better fit than Model $2\left(\Delta \chi 2_{(l)}=32, \mathrm{p}<\right.$ .01 ), Model 3 was then retained as the better depiction of the relationships between the constructs $\left(\chi^{2}=239, d f=79, \mathrm{CFI}=.98, \mathrm{TLI}=.97, \mathrm{RMSEA}=.04, \mathrm{SRMR}=.03\right)$. The results of the final model are displayed in Figure 2, with the standardised path coefficients listed next to 
the arrows of the specified relationships. Support for all of the hypothesised relationships was provided via statistically significant relationships within the structural model (HI: Sport identification and employee pride $=.16 ; H 2$ : Employee pride and job satisfaction $=.27$; and, $H 3$ : Employee pride and organisational citizenship behaviour $=.37$ ). Supplementary analysis also indicated that sport employee pride partially mediated the relationship between sport identification and the outcomes (Baron and Kenny, 1986; Mathieu and Taylor, 2006), with both sets of indirect effects being significant in the model (job satisfaction $\beta=.04$, Sobel $=3.8, \mathrm{SE}=$ $.01, \mathrm{p}<.01$; organisational citizenship behaviour $\beta=.06$, Sobel $=4.0, \mathrm{SE}=.01, \mathrm{p}<.01)$.

\section{--- INSERT FIGURE 2 ABOUT HERE ---}

\section{Discussion}

The current study examined positive organisational behaviour in professional sport using Todd and Kent's (2009) conceptual model as a framework for empirical understanding. In lieu of an established measure of positive social identity, sport employee pride was utilised as the focal construct of the hypothesised model. In addition, this study sought to empirically test the presence of identification with a specific sport, and its impact on employee pride in the current environment. The results of the structural equation modeling analysis provided support for all of the hypothesised relationships, and additional model comparisons further indicated a direct link from sport identification to both job satisfaction and organisational citizenship behaviour.

The results provide support for all of the hypothesised relationships. The analysis indicated a significant positive relationship exists between sport identification and employee pride $(H 1)$, however it should be noted that this effect is relatively small in magnitude $\left(R^{2}=.04\right)$. Contrary to expectations, identifying with a highly relevant aspect of the professional sport industry does not appear to be a major contributor to the amount of pride employees experience 
while working in this environment. As the participants consisted of business operations employees, one explanation could be that these individuals are generally more psychologically connected with the sport industry as a whole (e.g., Ashforth et al., 2008; Ashforth and Johnson, 2001) rather than with the specific sport that their organisation is affiliated with. Future research should consider this possibility and compare the potential role of sport industry identification with that of other industries (e.g., automotive, financial, and technology). While many working in this industry may be passionate about sport (Taylor et al., 2008), it could be that their affinity for sport more generally is paramount to any connection they have with a particular sport per se. This would suggest that using sport in general as a term for self-definition may ultimately be more essential than defining oneself in terms of only one sport (e.g., 'I'm a football person'). Future research should therefore consider the potential for identification with sport more generally, or the sport industry itself, as additional foci which might play a meaningful role for employees in this context.

The significant positive relationship between sport identification and both job satisfaction and organisational citizenship behaviour is also worthy of discussion. One reason for sport identification's positive influence on employee satisfaction may relate to the positive psychology experienced through one's aesthetic sensibility (Seligman and Csikszentmihalyi, 2000). As fans of a specific sport may be attentive to and appreciative of the physical skill and aesthetic beauty of certain sports (e.g., Trail et al., 2003), the sense of being immersed in this environment could then lead employees to more positively assess the general happiness level associated with their roles (Hackman and Oldham, 1975). As noted previously, the direct connection between sport identification and organisational citizenship behaviour may be related to the components of teamwork that are embedded within each concept. However, as the current analysis assessed 
organisational citizenship behaviour toward the organisation as a whole (rather than coworkers specifically), this relationship warrants further consideration. As these types of behaviours include taking action to protect and defend the organisation, it could be that employees who identify with the organisations' affiliated sport view their employer as a key ambassador for the game they love. For example, employees who work for Benetton Rugby Treviso and are also big fans of rugby may be more likely to act in ways which are supportive of the organisation partly because they perceive this to be supportive of Rugby in general. Future qualitative studies should look to probe the relationship between these constructs to better understand their connection.

The results also provided support for sport employee pride being a significant predictor of both job satisfaction (H2) and organisational citizenship behaviour (H3). Whilst sport identification also demonstrated direct links with job satisfaction and organisational citizenship behaviour, the results indicated that employee pride still had a slightly stronger influence on these outcomes. In the interest of promoting positive organisational behaviour in sport organisations, these outcomes are of particular relevance as they are indicative of employee happiness and supportive social and psychological working environment (Hackman and Oldham, 1975; Podsakoff, Whiting, Podsakoff and Blume, 2009; Wright, 2003). As we know of no other research which has specifically addressed these relationships in the sport management literature, the impact of sport employee pride appears to be worthy of further attention. Future research should therefore consider other important workplace outcomes such as organisational commitment and job involvement, which might also be influenced by the employee pride levels in sport.

The final structural model demonstrated very good fit with the data across four model fit indices, and also explained a medium to large amount of variance in job satisfaction $\left(R^{2}=.13\right)$ 
and organisational citizenship behaviour $\left(R^{2}=.22\right)$, respectively (Cohen, 1988). While we know of no previous research which measures sport identification and assesses its relationship with other workplace attitudes, one recent study worthy of comparison has assessed the impact of organisational identification and team identification on job satisfaction. Swanson and Kent's (2015) results indicated that these two identification constructs in unison have a large impact $\left(R^{2}\right.$ $=.27$ ) on job satisfaction for employees working in sport. As the current study addressed Swanson and Kent's (2015) call for identifying and testing additional sport-relevant foci of identification, future research should look to assess sport and team identification simultaneously to evaluate their combined effects in the sport workplace environment.

In addition, while very limited research has been conducted on employee pride in the sport context, one previous study has indicated that pride can have a positive effect on job selfefficacy (Todd and Harris, 2009). However, with pride being such an integral part of the sport environment in general (e.g., Chalip, 2006; Bang and Chelladurai, 2009; Heere et al., 2013; Wann, 2006), is seems likely that pride might also influence a variety of other important workplace outcomes, such as loyalty and commitment as seen in the consumer behaviour literature (e.g., Decrop and Derbaix, 2010). Additional research on the role of sport employee pride is therefore needed to increase our understanding in this area.

Overall this suggests that employee pride, in combination with sport identification, are two very important constructs in the positive organisational behaviour realm which are worthy of further investigation and have important implications in the sport workplace. In relation to employee pride, the results suggest that managers within the sport environment should recognise the importance of feeling important and valued, as it has a meaningful impact on general satisfaction and citizenship behaviours on behalf of the organisation. 
Perhaps the most interesting find in the current study, however, was the presence and impact of identifying with a specific type of sport. Implications for sport mangers are that employees can indeed have a psychological connection with the particular sport that the organisation is affiliated with, which in turn leads to increased levels of pride, satisfaction, and citizenship behaviour in the workplace. Human resource development programs may therefore wish to make a concerted effort to accentuate the defining aspects of their sports in the interest of promoting positive psychology in the sport workplace. In addition, sport identification might also play a role in recruiting and hiring decisions made by sport organisations. Although we would not suggest that being a fan supersedes the importance of skill set requirements for specific posts, the results here suggest that being a fan of the organisation's affiliated sport could also play a role in relation to person-organisation fit and the promotion of a positive work environment. Beyond the concept of 'working in sport' in its general sense, it appears that managers should also be aware of how their respective staff members might identify with the specific sport that their organisation represents.

\section{Future Research and Concluding Comments}

As we consider directions for future research, limitations of the current study should also be noted. As cross-sectional designs do not allow for conclusions to be made about causality or account for differences which might occur over time, future research should look to collect data at multiple points in time to address this issue. While the current study incorporated data with representation over five professional sports leagues, cross-validation of the model across alternate levels and geographical regions is also recommended. Of particular relevance may be testing this model within the Olympic structure of national governing bodies of sport. Similar results with this type of sample would increase the applicability beyond professional sport 
employees. In addition, the hypothesised model of the current study only addressed two of the main outcome variables in Todd and Kent's (2009) conceptual model. As little empirical research has been carried out in relation to this model which specifically addresses the sport workplace environment, it is recommended that futures sport studies include other constructs when testing the efficacy of the proposed relationships.

Another limitation to the current study was the use of employee pride as a proxy for Todd and Kent's (2009) conceptualization of positive social identity in the sport workplace. As their notion of psychological fulfillment is a broad concept with inherent complexities, it should be noted that utilising pride in the current study limited the ability to provide precise support for their propositions. However with no measure of their concept currently available, in our estimation employee pride is a construct with considerable overlap which can be operationalised using an existing validated scale from the literature. As we have not proposed that employee pride captures this psychological fulfillment in its entirety, future research should consider other constructs which have overlap with this concept. One clear choice would be self-esteem due to its relevance to positive social identity (Tyler and Blader, 2001), but other constructs from the positive organisational behaviour perspective like confidence, hope, and subjective well-being (e.g., Luthans, 2002) should also be considered.

With the recognition that professionals sport employees can identify with specific sports, future studies should extend this finding and consider the potential for additional targets of identification in the sport workplace. Our findings here extend the work of Swanson and Kent (2015) who found that professional sport employees identify with their affiliated sport teams, which leads to important attitudinal outcomes in the workplace. Future studies may wish to extend these findings and consider additional nested and cross-cutting targets of identification 
(e.g, Ashforth and Johnson, 2001) which are specifically applicable to sport organisations. With the results indicating that sport identification has a positive impact in the sport workplace, future studies should also look to consider its relationship with a variety of other workplace attitudes and behaviours. For example, the role of that sport identification might play in facilitating passion in the sport workplace (e.g., Anagnostopoulos, Winand, and Papadimitriou, 2016) is one particular area worthy of future consideration. Furthermore, with the current findings providing an additional target of identification highly relevant to the sport, there may also be scope for revising Todd and Kent's (2009) model to account for these newly found sport-specific predictors of workplace outcomes.

When considering the findings of the current study in relation to Todd and Kent's (2009) conceptual model, one construct which may be particularly relevant to sport identification is the notion of person-organisation fit (e.g., Cable and DeRue, 2002). It appears that this concept might play an important role as individuals become employed for sport organisations which are affiliated with only one specific sport. Person-organisation fit is situated within a larger framework of person-environment fit, which is broadly defined as the degree of match or compatibility between an individual and components of the work environment (Kristof-Brown, Zimmerman and Johnson, 2005). As being a sports fan can be of personal value to individuals (Wann, 2006), the concept of value congruence (i.e., perceived fit) might be an additional outcome of sport identification which has relevance to Todd and Kent's (2009) conceptual model. Future research should therefore look to assess employees' perceived fit in relation to identifying specific sports.

In summary, this study contributed to the sport management literature by identifying an additional target of identification which has relevance in the sport workplace environment. 
Beyond sport management, there is also potential for this concept to be extended to other industries that have a similar element which exists outside the organisation but also permeates the workplace environment. This study also contributes to the call for addition research in positive organisational behaviour by incorporating positively oriented psychological constructs into our empirical testing, and considering how these can be appropriately developed and managed (e.g., Luthans, 2002). By using sport employee pride as a measurable proxy for psychological fulfillment, the study also provides empirical support of the conceptual model proposed by Todd and Kent (2009). Finally, as the importance of identifying distinct aspects of our field has been noted in the sport management literature (e.g., Chalip, 2006; Slack, 1996), the role of sport identification and employee pride appear to represent fruitful pathways toward increased understanding of complexities within the sport workplace. 


\section{References}

Abeza, G., Pegoraro, A., Naraine, M. L., Séguin, B. and O'Reilly, N. (2014). Activating a global sport sponsorship with social media: an analysis of TOP sponsors, Twitter, and the 2014 Olympic Games. International Journal of Sport Management and Marketing, 15(3-4), 184-213.

Anagnostopoulos, C., Winand, M., and Papadimitriou, D. (2016). Passion in the workplace: empirical insights from team sport organisations. European Sport Management Quarterly, 16(4), 385-412.

Anderson, J. C. and Gerbing, D. W. (1988). Structural equation modeling in practice: A review and recommended two-step approach. Psychological Bulletin, 103(3), 411-423.

Ashforth, B. E., Harrison, S. H. and Corley, K. G. (2008). Identification in organizations: An examination of four fundamental questions. Journal of Management, 34(3), 325-374.

Ashforth, B. E., and Johnson S. A. (2001). Which hat to wear? The relative salience of multiple identities in organizational contexts. In M. A. Hogg and D. J. Terry (Eds.), Social identity processes in organizational contexts (pp. 31-48). Philadelphia, PA: Psychology Press.

Ashforth, B. E. and Mael, F. (1989). Social identity theory and the organization. Academy of Management Review, 14(1), 20-39.

Bang, H. and Chelladurai, P. (2009). Development and validation of the volunteer motivations scale for international sporting events (VMS-ISE). International Journal of Sport Management and Marketing, 6(4), 332-350.

Baron, R. M., and Kenny, D. A. (1986). The Moderator-Mediator variable the ModeratorMediator variable the Moderator-Mediator variable. Journal of Personality and Social Psychology, 51, 1173-1182. 
BBC.co.uk (2016). Sport: Get inspired. Retrieved March 7, 2016, from http://http://www.bbc.co.uk/sport/get-inspired/23152583

Blader, S. L. and Tyler, T. R. (2009). Testing and extending the group engagement model: linkages between social identity, procedural justice, economic outcomes, and extrarole behavior. Journal of Applied Psychology, 94(2), 445-464.

Brewer, M. B. and Kramer, R. M. (1986). Choice behavior in social dilemmas: Effects of social identity, group size, and decision framing. Journal of Personality aid Social Psychology, 50(3), 543-549.

Cable, D. M. and DeRue, D. S. (2002). The convergent and discriminant validity of subjective fit perceptions. Journal of Applied Psychology, 87(5), 875-884.

Cable, D. M. and Judge, T. A. (1996). Person-organization fit, job choice decisions, and organizational entry. Organizational Behavior and Human Decision Processes, 67(3), 294-311.

Cammann, C., Fichman, M., Jenkins, G. D., Jr. and Klesh, J. R. (1983). Assessing the attitudes and perceptions of organizational members. In S. E. Seashore, E. E. Lawler, P. H. Mirvis, and C. Cammann (Eds.), Assessing organizational change: A guide to methods, measures, and practices (pp. 71-138). New York, NY: Wiley.

Cardador, M. T., Dane, E. and Pratt, M. G. (2011). Linking calling orientations to organizational attachment via organizational instrumentality. Journal of Vocational Behavior, 79(2), 367-378.

Caspar, J. M. and Menefee, W. C. (2010). Prior sport participation and spectator sport consumption: Socialization and soccer. European Sport Management Quarterly, 10(5), 595-611. 
Chalip, L. (2006). Toward a distinctive sport management discipline. Journal of Sport Management, 20, 1-21.

Cohen, J. (1988). Statistical power analysis for the behavioral sciences (2nd ed.). Hillsdale, NJ: Lawrence Erlbaum.

Decrop, A. and Derbaix, C. (2010). Pride in contemporary sport consumption: a marketing perspective. Journal of the Academy of Marketing Science, 38(5), 586-603.

Dickson, G., Naylor, M. and Phelps, S. (2015). Consumer attitudes towards ambush marketing. Sport Management Review, 18(2), 280-290.

Dittmore, S. W., Stoldt, G. C. and Greenwell, T. C. (2008). Use of an organizational weblog in relationship building: the case of a Major League Baseball Team. International Journal of Sport Communication, 1(3), 387-397.

Doherty, A. J. (1998). Managing our human resources: A review of organisational behaviour in sport. Sport Management Review, 1(1), 1-24.

Dutton, J. E., Dukerich, J. M., and Harquail, C. V. (1994). Organizational images and member identification. Administrative Science Quarterly, 39(2), 239-263. Ellemers, N., Kingma, L., van de Burgt, J. and Barreto, M. (2011). Corporate social responsibility as a source of organizational morality, employee commitment and satisfaction. Journal of Organizational Moral Psychology, 1(2), 97-124.

Evans, N. J., and Jarvis, P. A. (1986). Group attitude scale. Small Group Behavior, 17, 203-216.

Ferrin, D. L., Dirks, K. T. and Shah, P. P. (2006). Direct and indirect effects of third-party relationships on interpersonal trust. Journal of Applied Psychology, 91(4), 870-883.

Fornell, C. and Larcker, D. (1981). Structural equation models with unobservable variables and measurement error. Journal of Marketing Research, 19(3), 382-388. 
Gau, L. S. and Woodside, A. G. (2014). I am (not) a basketball person: Self-sport brand-me relationships among basketball spectators. Journal of Physical Education and Sport Management, 5(3), 39-44.

Gouthier, M. H. J. and Rhein, M. (2011). Organizational pride and its positive effects on employee behavior. Journal of Service Management, 22(5), 633-649.

Hackman, J. R. and Oldham, G. R. (1975). Development of the job diagnostic survey. Journal of Applied Psychology, 60(2), 159-170.

Hair, J. F., Black, W. C., Babin, B. J., Anderson, R. E. and Tatham, R. L. (2006). Multivariate Data Analysis (6th ed.). Upper Saddle River, NJ: Pearson Education.

Heere, B., Walker, M., Gibson, H., Thapa, B., Geldenhuys, S and Coetzee, W. (2013). The power of sport to unite a nation: The social value of the 2010 FIFA World Cup in South Africa. European Sport Management Quarterly, 13(4), 450-471.

Hulland, J. (1999). Use of partial least squares (PLS) in strategic management research: A review of four recent studies. Strategic Management Journal, 20, 195-204.

Jiang, J. T., Klein, G. and Carr, C. L. (2002). Measuring information system service quality: SERVQUAL from the other side. MIS Quarterly, 26(2), 145-166.

Kristof-Brown, A. L. Zimmerman, R. D., and Johnson, E. C. (2005). Consequences of individuals fit at work: A meta-analysis of person-job, person-organization, persongroup, and person-supervisor fit. Personnel Psychology, 58(2), 281-342.

Lee, K. and Allen, N. J. (2002). Organizational citizenship behavior and workplace deviance: the role of affect and cognitions. Journal of Applied Psychology, 87(1), 131-142.

Leedy, D. L. and Ormrod, J. E. (2001). Practical Research (7th ed.). Upper Saddle River, NJ: Prentice-Hall. 
Luthans, F. (2002). Positive organizational behavior: Developing and managing psychological strengths. Academy of Management Executive, 16(1), 57-75.

MacIntosh, E., Arellano, A. and Forneris, T. (2016). Exploring the community and externalagency partnership in sport-for-development programming. European Sport Management Quarterly, 16(1), 38-57.

Maraniss, D. (1999). When pride still mattered: A life of Vince Lombardi. New York: Simon and Schuster.

Mathieu, J. E., and Taylor, S. R. (2006). Clarifying conditions and decision points for mediational type inferences in Organizational Behavior. Journal of Organizational Behavior, 27(8), 1031-1056.

Misener, L. and Mason, D. S. (2009). Fostering community development through sporting events strategies: An examination of urban regime perceptions. Journal of Sport Management, 23(6), 770-794.

MLB.com (2016). Major League Baseball careers. Retrieved March 7, 2016, from http://http://mlb.mlb.com/careers/index.jsp?loc=ocb

Muthén, L. K. and Muthén, B. O. (1998-2012). Mplus User's Guide (7th Ed.). Los Angeles, CA: Muthén and Muthén.

Organ, D. W. (1988). Organizational citizenship behavior: the good soldier syndrome. Lexington, MA: Lexington Books.

Organ, D. W. (1990). The motivational basis of organizational citizenship behavior. In B. M. Staw and L. L. Cummings (Eds.), Research in Organizational Behavior (Vol. 12, pp. 4372). Greenwich, CT: JAI. 
Podsakoff, N. P., Whiting, S. W., Podsakoff, P. M. and Blume, B. D. (2009). Individual- and organizational-level consequences of organizational citizenship behaviors: A metaanalysis. Journal of Applied Psychology, 94(1), 122-141.

Rowe, D., Markwell, K. and Stevenson, D. (2006). Exploring participants' experiences of the Gay Games: Intersections of sport, gender and sexuality. International Journal of Media and Cultural Politics, 2(2), 149-165.

Schneider, B. (1987). The people make the place. Personnel Psychology, 40(3), 437-453.

Seligman, M. E. P. and Csikszentmihalyi, M. (2000). Positive psychology. American Psychologist, 55(1), 5-14.

Shemilt, S. (2013). BBC Sport. Retrieved March 7, 2016, from http://http://www.bbc.co.uk/sport/rugby-league/24481185

Sokolowski, R. (2001). Friendship and moral action in Aristotle. The Journal of Value Inquiry, $35(3), 355-369$.

Swanson, S. and Kent, A. (2014). The complexity of leading in sport: Examining the role of domain expertise in assessing leader credibility and prototypicality. Journal of Sport Management, 28(1), 81-93.

Swanson, S. and Kent, A. (2015). Fandom in the workplace: Multi-target identification in professional sports. Journal of Sport Management, 29(4), 461-477.

Tajfel, H. (1978). Social categorization, social identity and social comparison. In H. Tajfel (Ed.), Differentiation between social groups: Studies in the social psychology of intergroup relations (pp. 61-76). London, England: Academic Press. 
Tajfel, H. and Turner, J. C. (1979). An integrative theory of intergroup conflict. In W. G. Austin and S. Worchel (Eds.), The social psychology of group relations (pp. 33-47). Monterey, CA: Brooks-Cole.

Tajfel, H. and Turner, J. C. (1986). The social identity theory of intergroup behavior. In S. Worchel and W. G. Austin (Eds.), Psychology of intergroup relations (pp. 7-24). Chicago: Nelson-Hall.

Taylor, T. Doherty, A., and McGraw, P. (2008). Managing people in sport organizations: A strategic human resource management perspective (1st ed.). New York, NY: Routledge.

Todd, S. Y., and Andrew, D. P. S. (2008). An exploratory investigation of sport management students' attraction to sport jobs. International Journal of Sport Management and Marketing, 4(4), 323-337.

Todd, S. Y. and Harris, K. J. (2009). What it means when your work is admired by others: Observations of employees of professional sport organizations. Journal of Behavioral and Applied Management, 10(3), 396-414.

Todd, S. and Kent, A. (2009). A social identity perspective on the job attitudes of employees in sport. Management Decision, 47(1), 173-190.

Trail, G. T., Robinson, M. J., Dick, R. J. and Gillentine, A. J. (2003). Motives and points of attachment: Fans versus spectators in intercollegiate athletics. Sport Marketing Quarterly, 12(4), 217-227.

Tyler, T. (2001). Cooperation in organizations: A social identity perspective. In M. A. Hogg and D. J. Terry (Eds.), Social identity processes in organizational contexts (pp. 149-165). Philadelphiia, PA: Psychological Press. 
Tyler, T. R. and Blader, S. L. (2001). Identity and cooperative behavior in groups. Group processes and Intergroup Relations, 4(3), 207-226.

Tyler, T., Degoey, P. and Smith, H. (1996). Understanding why the justice of group procedures matters: A test of the psychological dynamics of the group-value model. Journal of Personality aid Social Psychology, 70(5), 913-930.

Wann, D. and Branscombe, N. (1993). Sports fans: Measuring degree of identification with their team. International Journal of Sport Psychology, 24, 1-17.

Wann, D. L. (1997). Sport Psychology. Upper Saddle River, NJ: Prentice-Hall, Inc.

Wann, D. L. (2006). The causes and consequences of sport team identification. In A. A. Raney and J. Bryant (Eds.), Handbook of sports and media (pp. 331-352). Mahwah, NJ: Erlbaum.

Wann, D. L. and Branscombe, N. R. (1990). Die-hard and fair-weather fans: Effects of identification on BIRGing and CORFing tendencies. Journal of Sport and Social Issues, 14(2), 103-117.

Wärnå, C., Lindholm, L. and Eriksson, K. (2007). Virtue and health-finding meaning and joy in working life. Scandinavian Journal of Caring Sciences, 21(2), 191-198.

Weinberg, R. S. and Gould, D. (2011). Foundations of sport and exercise psychology (5th ed.). Champaign, IL: Human Kinetics.

Wright, T. (2003). Positive organizational behavior: An idea whose time has truly come. Journal of Organizational Behavior, 24(4), 437-442. 


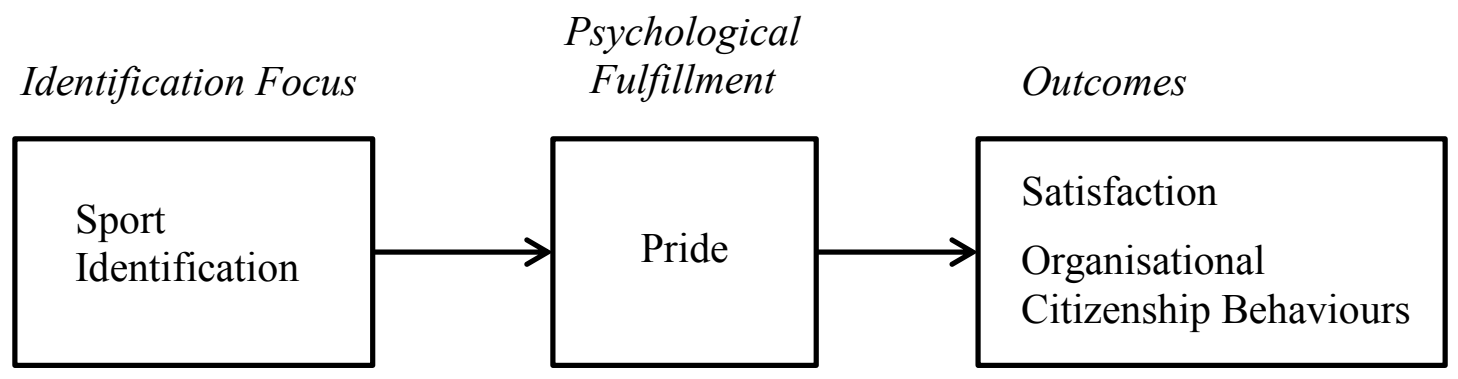

Figure 1. Model of employee pride in professional sport organisations.

Table 1. Correlation matrix

\begin{tabular}{|c|c|c|c|c|c|c|c|c|c|}
\hline & & $M$ & $\alpha$ & $\mathrm{CR}$ & AVE & 1 & 2 & 3 & 4 \\
\hline 1. & Pride & 4.17 & .89 & .89 & .73 & 1.00 & & & \\
\hline 2. & Sport identification & 6.62 & .94 & .95 & .81 & .16 & 1.00 & & \\
\hline 3. & Job satisfaction & 4.39 & .85 & .85 & .66 & .29 & .25 & 1.00 & \\
\hline 4. & OCB & 5.53 & .70 & .70 & .44 & .40 & .29 & .57 & 1.00 \\
\hline
\end{tabular}

All values significant $(p<.01) ; M=$ aggregated mean; $\alpha=$ Cronbach's alpha; $\mathrm{CR}=$ construct reliability; $\mathrm{AVE}=$ average variance extracted.

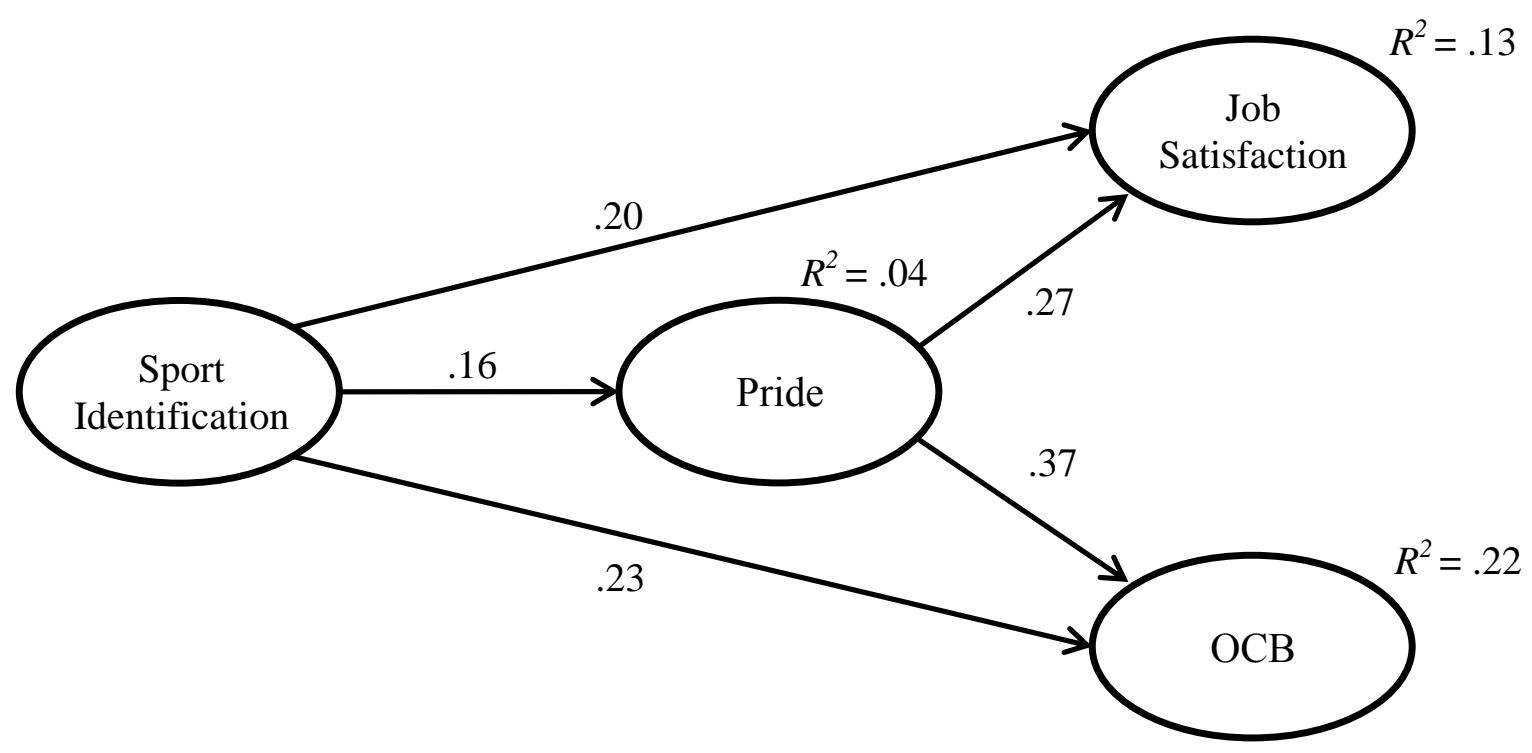

Figure 2. Final Structural Model Note. All parameter estimates significant at $p<.01$ 